Benha Veterinary Medical Journal
Official Journal Issued by
Faculty of
Veterinary Medicine Journal homepage: https://bvmj.journals.ekb.eg/

Original Paper

\title{
Clinical study on Moraxella-associated infectious keratoconjunctivitis (IKC) of small ruminants
}

Ahmed M. A. Zaitoun ${ }^{1}$, Mohamed G.A. Elseleny ${ }^{2}$, and Khaled A.S. El-Khabaz ${ }^{{ }^{*}}$

${ }^{I}$ Department of Animal Medicine (Infectious Diseases), Faculty of Veterinary Medicine, Assiut university, Egypt.

${ }^{2}$ Assiut Directorate of Veterinary Medicine

\begin{tabular}{|c|c|}
\hline ARTICLE INFO & ABSTRACT \\
\hline $\begin{array}{l}\text { Keywords } \\
\text { Infectious } \\
\text { keratoconjunctivitis } \\
\text { Moraxella } \\
\text { small ruminants } \\
\text { Antimicrobial sensitivity } \\
\text { test and field therapeutic } \\
\text { trials }\end{array}$ & $\begin{array}{l}\text { Infectious keratoconjunctivitis (IKC) represents an important health problem in semi-desert } \\
\text { and desert areas. The present study tries to investigate the possible role of Moraxella as a } \\
\text { causative agent of IKC. A total number of } 140 \text { sterile conjunctival swabs from the diseased } \\
\text { animals ( } 93 \text { sheep and } 47 \text { goats) of different ages showed signs of IKC were subsequently } \\
\text { collected, bacteriologically examined to isolate Moraxella spp, which was successively } \\
\text { isolated from } 19 \text { animals ( } 11 \text { sheep and } 8 \text { goats) with infection rate about } 13.6 \% \text {. In relation to } \\
\text { age, a higher infection rate }(19.2 \% \text { ) was recorded among sheep in the age group } \geq 12 \text { to }<24 \\
\text { months and among goats in the age group } \geq 3 \text { to }<6 \text { months. Antimicrobial sensitivity test of } \\
\text { obtained isolates revealed that Moraxella was } 100 \% \text { sensitive to Ciprofloxacin, Gentamicin, } \\
\text { and Tylosin, and } 79 \% \text { to Oxytetracycline. All tested isolates were resistant to Vancomycin, } \\
\text { Ampicillin plus Sulbactam, and Sulfamethoxazole plus Trimethoprim. Therapeutically, two } \\
\text { therapeutic regimens were carried out to treat the diseased cases under field conditions and the } \\
\text { results were illustrated in detail. }\end{array}$ \\
\hline
\end{tabular}

\section{INTRODUCTION}

Infectious keratoconjunctivitis (IKC) of small ruminants is an outstanding problem causing a considerable level of economic losses in sheep and goats flocks. Clinically the disease can be recognized by progressive cloudiness of eye, severe congestion of ocular mucous membrane with inflammation of cornea, ocular discharges vary from serous to purulent and temporary or permanent blindness (Baker et al., 2001 and Abdullah et al., 2014). There are several pathogens were incriminated as etiologic agent responsible for IKC. However, Moraxella with and/or without other pathogens was implicated as a major pathogen causes IKC in small and large ruminants (Abdullah et al., 2015; Gelormini, et al., 2017 and Zheng et al., 2019). Moreover, frequent isolation of different microorganisms from ruminants with signs of IKC may attributed to the synergistic action between environmental risk factors and opportunistic pathogens habitat eye (Sağlam etal., 2018). However, Moraxella spp was isolated as single pathogen from outbreaks of IKC in sheep and goats flocks (Karthik et al., 2017 and Athira et al., 2018).

Etiologically, Moraxella are Gram negative diplococci, nonmotile and catalase and oxidase positive, easily transmitted by contact with nasal and ocular discharges and by flies as mechanical transmitter (Ojo et al., 2009 and Athira et al., 2018). Moraxella ovis was found to produce one or more heat-labile exotoxins causing both hemolysis for bovine RBCs and cytotoxic activities against corneal tissues (Cerny et al., 2006). Moraxella spp has the ability to form biofilm but in vivo, this character reduced by the action of lysozyme naturally present in tears (Ely et al., 2018). Different prevalence rates of Moraxella associated infectious keratoconjunctivitis have been observed by several authors (Van Halderen et al., 1994; Naglić et al., 2000 and Karthik et al., 2017). There are different outcomes of various therapeutic trials used for IKC. Variations in results of antimicrobials susceptibility were noticed between Moraxella spp isolates of different regions. this may refer to differences in genotyping characters of isolates (Loy and Brodersen, 2014). Cure rate of $100 \%$ can be achieved by using various types of antibiotics systemically by injection along with topical antibiotic eye preparations (Pandey, 2018 and Sağlam et al., 2018). Role of Moraxella spp in sheep and goats with signs of IKC is aimed. Epidemiological notes of IKC of both sheep and goats was monitored and antibiogram followed by field-therapeutic trials of the diseased cases were also carried-out.

\section{MATERIAL AND METHODS}

\subsection{Study area:}

The study was carried out on El-Ghaniem, Assiut governorate - Egypt. This city located next to Assiut's Western Mountain with hot weather and high humidity during summer months. In winter, there no rains and the climatic temperature is warm at day and cool at night. Topographically, El-Ghanien is semi-desert and desert land. Sheep and goats located in desert area of El-Ghaniem rather than the semi-desert areas.

\footnotetext{
* Corresponding author: Khaled A.S. El-Khabaz, Department of Animal Medicine (Infectious Diseases), Faculty of Veterinary Medicine, Assiut university, Egypt.
} 


\subsection{Animals and sampling:}

During the period of investigation (2019 - 2020), a total number of 93 sheep and 47 goats (140 animals) of different ages were clinically examined according to (Jackson and Cockcroft, 2002) for the presence of signs of IKC. Aseptically, conjunctival swab was taken from each diseased case. The swabs were immediately inoculated in sterile tubes containing Trypticase Soy broth (Titan media India) and transported in ice tank to the bacteriological laboratory unit, Infectious Diseases, Faculty of Veterinary Medicine, Assiut University, with minimum of delays.

2.3 Bacteriological examination:

Tubes containing broth were incubated at $37{ }^{\circ} \mathrm{C}$ for $24 \mathrm{~h}$. A bacteriological loopful from each tube was streaked onto 5\% blood agar (Lab M limited-UK) plate and incubated at $37^{\circ} \mathrm{C}$ for $24-48 \mathrm{~h}$ with daily examination for any colony growth. The suspected colonies were picked-up, recultured and thereafter subjected to biochemical identification based on criteria illustrated by Baron et al., (1994) and Quinn et al., (1994). These criteria include Gram staining followed by indole, oxidase, motility, sugar-fermentation, Simmon's citrate and Catalase tests. Morphologically, target colonies were being small $(1 \mathrm{~mm})$, friable, grayish-white and surrounded with narrow zone of complete hemolysis. Biochemically, Moraxella spp were being positive for oxidase and catalase tests while being negative for Gram staining, indole, motility, Simmon's citrate and fermentation tests.

2.4. Antibiogram and therapeutic trails:

On Mueller-Hinton agar (Accumedia-India), all Moraxella isolates were tested for their antimicrobials sensitivity according to Bauer et al., (1966) using commercial antimicrobial discs (Mast Diagnostics - U.K.). Ampicillin plus Sulbactam $20 \mu \mathrm{g}$, Vancomycin $30 \mu \mathrm{g}$, Ciprofloxacin 5 $\mu \mathrm{g}$, Gentamicin $10 \mu \mathrm{g}$, Oxytetracycline $30 \mu \mathrm{g}$, Sulfamethoxazole plus Trimethoprim $25 \mu \mathrm{g}$ and Tylosin 30 $\mu \mathrm{g}$ were used.

Based on the results of sensitivity tests, two therapeutic regimens were used, the first regimen include: injection of long acting oxytetracycline I.M. (Alamycin L.A®) by $1 \mathrm{ml} /$ $10 \mathrm{~kg}$ every $48 \mathrm{~h}$, I.M injection of diclofenac sodium (Dicloprima $\left.{ }^{\circledR}\right) 1 \mathrm{ml} / 25 \mathrm{~kg}$ (in feverish cases), I.M injection of AD3E (Devedry Med®) $1 \mathrm{ml} / 25 \mathrm{~kg} / 12 \mathrm{~h}$ for 3 successive days and after eye washing with Boric acid lotion $2 \%$, topical eye ointment (Terramycin $\left.{ }^{\circledR}\right)$ was applied 3 times daily for 3 successive days. The second therapeutic regimen include: I.M injection of Tylosin plus Gentamicin (Tylogent reforzado®) $1 \mathrm{ml} / 25 \mathrm{~kg} / 12 \mathrm{~h}$, I.M injection of Flunixin meglumine (Finadyne $\left.{ }^{\circledR}\right) 1 \mathrm{ml} / 25 \mathrm{~kg}$ (for feverish cases), I.M injection of AD3E (Devedry Med®) $1 \mathrm{ml} / 25 \mathrm{~kg} / 12 \mathrm{~h}$ for 3 successive days and after eye washing with Boric acid lotion $2 \%$, topical eye drop containing Tobramycin + Dexamethasone (Dexatobrin ${ }^{\circledR}$ ) was applied 3 times daily for 3 successive days.

\section{RESULTS}

\subsection{Clinical findings:}

Of the examined animals, 19 (13.6 \%) cases showed dramatic signs of conjunctivitis, keratitis with different degrees of corneal opacities either unilateral $(6 / 19,31.6 \%)$ or bilateral $(13 / 19,68.4 \%)$. The ocular discharge was mucopurulent and obviously blepharospasm (Fig 1). Feverish condition $(10 / 19,52.6 \%)$, tachycardia and tachypnea, nasal discharge, corneal ulcers, restlessness, separation from the flock and reduction in feed intake were clinically monitored in some diseased animals.

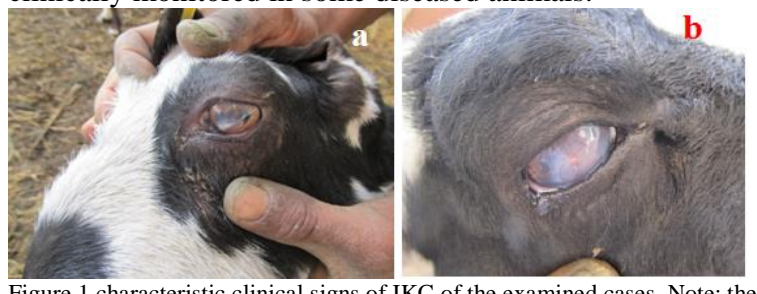

Figure 1 characteristic clinical signs of IKC of the examined cases. Note: the moderate degree of opacity in Left case (a) in contrast the right case (b) shows severe cloudiness corneal opacity.

\subsection{Bacteriological and Antimicrobial sensitivity results:}

The current bacteriological examinations and biochemical identification revealed that Moraxella species were successively isolated from 19 out of 140 clinically diseased cases with signs of IKC. All tested Moraxella strains were 100\% sensitive to Ciprofloxacin, Gentamicin and Tylosin. the susceptibility to Oxytetracycline was $78.9 \%$ (15/19). The tested strains were resistant to Ampicillin plus Sulbactam, Vancomycin and Sulfamethoxazole plus Trimethoprim.

\subsection{Therapeutic trail results:}

The recovery rate for these Moraxella spp infected animals $(n=19)$ with first therapeutic regimens was about $74 \%(14$ out of 19), the 5 non-responsive cases when subjected to second therapeutic regimens, the cure recovery rate was $100 \%$.

\subsection{Epidemiological investigation:}

Out of 140 tested animals with signs of IKC, Moraxella spp were isolated from 19 animals (11 sheep and 8 goats) with a prevalence rate about $13.6 \%$. The prevalence rate of Moraxella infection among sheep was $11.8 \%$ (11 out of 93) while among goats $17 \%$ ( 8 out of 47 ). The relationship between the prevalence of Moraxella associated IKC and age was illustrated in table 1.

Table 1 Infection rate of Moraxella-positive cases of the examined sheep and goats in relation to age of examined animals.

\begin{tabular}{lllllll}
$\begin{array}{l}\text { Age } \\
\text { groups } \\
\text { per month }\end{array}$ & \multicolumn{2}{c}{ Sheep } & \multicolumn{3}{c}{ Goats } \\
& No. & \multicolumn{2}{c}{+ ve Moraxella } & No. & \multicolumn{2}{c}{ +ve Moraxella } \\
& & No. & $\%$ & & No. & $\%$ \\
\hline$<3$ & 9 & 0 & 0.0 & 5 & 0 & 0.0 \\
$\geq 3-<6$ & 23 & 1 & 4.4 & 7 & 2 & 28.6 \\
$\geq 6-<12$ & 30 & 5 & 16.7 & 16 & 4 & 25 \\
$\geq 12-<24$ & 26 & 5 & 19.2 & 16 & 2 & 12.5 \\
$\geq 24$ & 5 & 0 & 0.0 & 3 & 0 & 0.0 \\
Total & 93 & 11 & 11.8 & 47 & 8 & 17 \\
\hline
\end{tabular}

\section{DISCUSSION}

Sheep and goats occupied the second grade following buffaloes and cattle in Egypt as a source of Meat and economic incomes. However, in semi-desert and desert areas of Assiut Governorate like El-Ghaniem, the population density of sheep and goat are more than large ruminant. Currently, IKC representing a considerable health problem for sheep and goats flocks (Hidson and Winter, 2008). The observed clinical findings strongly refer to IKC. Similar clinical findings were reported previously (Ojo et al., 2009 and Karthik et al., 2017).

Although different microorganisms were encountered as causative agents of IKC in small ruminant, Moraxella and Mycoplasma appear to be the most important one (Åkerstedt 
and Hofshagen, 2004). In the present study Moraxella was successively isolated from 19 cases of 140 examined animals $(13.6 \%)$. the low isolation rate of Moraxella may give an indication that IKC is a multi-complexes and Moraxella is not the only pathogen responsible for IKC in small ruminant. IKC caused by different microorganisms and the presence of risk factors is crucial (Van Halderen et al., 1994; Jansen et al., 2006; Åkerstedt and Hofshagen, 2004 and Pandey, 2018).

In the current study the prevalence of Moraxella spp among the diseased sheep and goats was $11.8 \%$ and $17 \%$ respectively which come in agree with Jansen et al., (2006) who reported prevalence of Moraxella among bighorn sheep and domesticated goats about $29 \%$, and $18.8 \%$, respectively. Also, Akerstedt and Hofshagen (2004) recorded a prevalence rate about $14 \%$ (6/43) among IKC diseased Norwegian sheep. Moraxella ovis was isolated from $85.7 \%$ of affected sheep with IKC (Sağlam, et al., 2018). Moraxella was isolated from $100 \%$ of diseased goats $(n=8)$ (Ojo et al., 2009). Variation in prevalence rates may be attributed to differences in the number of examined animals and distinction in managemental and environmental conditions in different localities where the studies were conducted. Epidemiologically, from geographical point of view, the study area located next to the western mountain increasing the chance for corneal dryness and corneal abrasion caused by aero-sandy particles carried by wind, as well as exposure to high percentage of ultraviolet rays which may predispose for Moraxella colonization. Different environmental predisposing factors are greatly needed for Moraxella to precipitate their characteristic clinical signs, furthermore, the presence of corneal hurt by mechanical factors or ultraviolet irradiation is important for occurrence of the disease (Dubay et al., 2000). However, Moraxella was isolated as a single pathogen from goats with characteristic signs of IKC (Athira et al., 2018).

In relation to age, the infection rate of Moraxella associated IKC was high in sheep in the age group $\geq 12$ to $<24$ months while in goats in the age group $\geq 3$ to $<6$ months. Zero prevalence was recorded in sheep and goats aged less than 3 months and more than 24 months. This may be due to the small number of studied animals in these age groups or due to a build-up immunological status as maternal immunity in young and developed acquired immunity in aged cases. Variation in the prevalence rate in relation to age was noticed by (Naglić et al., 2000), the authors could isolate Moraxella from $44 \%$ in the age group less than 1 year, $33 \%$ from sheep aged 1-3 years and 22\% from those more than 3 years.

Therapeutically, the results of the first regimens of therapeutic trail that depends on usage of oxytetracycline systemically and topically come in accordance with the results of antimicrobial sensitivity test as the sensitivity of Moraxella to Oxytetracycline was $78.9 \%$. The susceptibility rate of Moraxella of small and large ruminants to oxytetracycline ranged from $80 \%$ to $91 \%$ and the haphazard use of oxytetracycline in veterinary practice contributed to the emergence of resistant strains (Maboni et al., 2015). Using of oxytetracycline topically as eye ointment and systemically by injection gives better results with a rare relapse rate (Naglić et al., 2000 and Pandey, 2018). On the other side, the 5 non-responsive cases when shifting to the second therapeutic regimens, they were responded well with $100 \%$ cure recovery rate. this was harmonious with the results of antimicrobial sensitivity testing. Currently, Moraxella isolates were $100 \%$ sensitive to Tylosin and Gentamicin. By disk diffusion technique, Moraxella were resistant to penicillin, ampicillin, cloxacillin and chloramphenicol while being $100 \%$ susceptible to gentamicin and ofloxacin (Ojo et al., 2009).

\section{CONCLUSION}

Infectious keratoconjunctivitis is serious problem of small ruminant located in semi-desert and desert areas. Moraxella infection was bacteriologically identified as an important pathogen causing IKC. However, further studies should be warranted to determine the other possible pathogens responsible for IKC in particular Mycoplasma infection and epidemiological determinants need further investigation. Systemic and topical antimicrobials increase the recovery rate. Tylosin, gentamicin or ciprofloxacin are drugs of choice.

\section{REFERENCES}

1. Abdullah, F.F.J., Radzuan, N.S., Tijjani, A., Adamu, L., Abba, Y., Mohammed, K., Osman, A.Y., Roslim, N., Awang, D.N., Saharee, A.A. et al. 2014. Stage II keratoconjunctivitis in a goat: a case report. IOSR Journal of Agriculture and Veterinary Science 7, 16-18.

2. Abdullah, F.F.J., Naidu, N.R.G., Sadiq, M.A., Abba, Y., Tijjani, A., Mohammed, K., Chung, E.L.T., Norsidin, M.J.M., Lila, M.A.M., Haron, A. et al., 2015. Prevalence of Moraxella ovis Infection in Goats under the Ladang Angkat Programme, Universiti Putra Malaysia: A Cross-Sectional Study. IOSR Journal of Agriculture and Veterinary Science 8 (11 Ver. I), 99102. DOI: $10.9790 / 2380-0811199102$.

3. Åkerstedt, J. and Hofshagen, M. 2004. Bacteriological Investigation of Infectious Keratoconjunctivitis in Norwegian Sheep. Acta veterinaria Scandinavica 45 (12), 19-26

4. Athira, G.R., Chandrasekaran, D., Arunaman, C.S., Senthil, N.R. and Vaiaramuthu, S. 2018. Successful management of keratoconjunctivitis in goats in Chennai. Journal of Applied and Natural Science 10(4), 1196-1198.

5. Baker, S.E., Bashiruddin, J.B., Ayling, R.D. and Nicholas, R.A. 2001. Molecular detection of Mycoplasma conjunctivae in English sheep affected by infectious keratoconjunctivitis. Veterinary Record 148, 240-241.

6. Baron, E.J., Peterson, L.R. and Finegold, S.M. 1994. In: Bailey \& Scott's Diagnostic Microbiology. 9th edit.

7. Bauer, A. W., Kirby, W. M. M., Sherris, J. C., and Turck, M. 1966. Antibiotic susceptibility testing by a standardized single disk method. American Journal of Clinical Pathology 45,493-496.

8. Cerny, H.E., Rogers, D.G., Gray, J.T., Smith, D.R. and Hinkley, S. 2006. Effects of Moraxella (Branhamella) ovis Culture Filtrates on Bovine Erythrocytes, Peripheral Mononuclear Cells, and Corneal Epithelial Cells. Journal of Clinical Microbiology 44(3), 772-776. https://doi.org/10.1128/JCM.44.3.772-776.2006.

9. Dubay, S.A., Williams, E.S., Mills, K. and BoergerFields, A.M. 2000. Association of Moraxella ovis with keratoconjunctivitis in mule deer and moose in Wyoming. Journal of Wildlife Diseases 36(2), 241247.

10. Ely, V.L., Vargas, A.C., Costa, M.M., Oliveira, H.P., Pötter, L., Reghelin, M.A., Fernandes, A.W., Pereira, D.I.B., Sangioni, L.A. and Botton, S.A. 2018. Moraxella bovis, Moraxella ovis and Moraxella bovoculi: biofilm formation and lysozyme activity. 
Journal of Applied Microbiology 126, 369-376. doi:10.1111/jam.14086.

11. Gelormini, G., Gauthier, D., Vilei, E.M., Crampe, J.P., Frey, J. and Degiorgis, M.P.R. 2017. Infectious keratoconjunctivitis in wild Caprinae: merging field observations and molecular analyses sheds light on factors shaping outbreak dynamics. BMC Veterinary Research 13, 67. DOI 10.1186/s12917-017-0972-0.

12. Hidson, J.C. and Winter, A.C. 2008. Manual of Sheep Diseases. The 2nd Ed., Pp 158 - 162. Blackwell Scientific.

13. Jackson, P.G.G. and Cockcroft, P.D. 2002. clinical examination of farm animals. A textbook. 1st edi. Chapters 15\&17. Blackwell Science Ltd, Oxford OX20EL, UK .

14. Jansen, B.D., Heffelfinger, J.R., Noon, T.H., Krausman, P.R. and Devos, J.C. 2006. Infectious keratoconjunctivitis in bighorn sheep, Silver Bell Mountains, Arizona, USA. Journal of Wildlife Diseases 42(2), 407-411.

15. Karthik, K., Manimaran, K., Mahaprabhu, R. and Shoba, K. 2017. Isolation of Moraxella sp. From Cases of Keratoconjunctivitis in an Organized Sheep Farm of India. Open Journal of Veterinary Medicine 7, 138-143. https://doi.org/10.4236/ojvm.2017.710014.

16. Loy, J.D. and Brodersen, B.W. 2014. Moraxella spp isolated from field outbreaks of infectious bovine keratoconjunctivitis: a retrospective study of case submissions from 2010 to 2013. Journal of Veterinary Diagnostic Investigation 26(6), 761-768. DOI: 10.1177/1040638714551403.

17. Maboni, G., Gressler, L.T., Espindola, J.P., Schwab, M., Tasca, C., Potter, L., Castagna de Vargas, A. 2015. Differences in the antimicrobial susceptibility of Moraxella bovis, $\mathrm{M}$ bovoculi and $\mathrm{M}$ ovis. Brazilian Journal of Microbiology 46(2), 545-549. DOI: http://dx.doi.org/10.1590/S1517-838246220140058.
18. Naglić, T., Hajsic, D., Frey, J., Šeol, B., Busch,K. and Lojkić, M. 2000. Epidemiological and microbiological study of an outbreak of infectious keratoconjunctivitis in sheep. Veterinary Record 147, 72-75.

19. Ojo, O.E., Oluwole, O.A. and Adetosoye, A.I. 2009. Isolation of Moraxella bovis from infectious keratoconjunctivitis in a flock of goats. Nigerian veterinary journal 30(1), 56-59. DOI: $10.4314 / \mathrm{nvj}$. v30i1.65162.

20. Pandey, G.S. 2018. An outbreak of infectious caprine kerato-conjunctivitis in a flock of goats - case report. Indian Journal of Animal Health 57(1), 103-108 .

21. Quinn, P. J., Carter, M.E., Markey, B. and Carter G.R. (eds.) 1994. Clinical veterinary micro-biology. MosbyYearbook Europe Limited, London, UK, pp 290.

22. Sağlam, A.G., Erkiliç, E.E., Büyük, F., Kirmizigül, A.H., Gökçe, G., Balyen, L., Akyüz, E., Aydin, U, Özba, B. and Otlu, S. 2018. Moraxella ovis and Mycoplasma conjunctivae isolation from an ovine infectious keratoconjunctivitis outbreak and fortified treatment approaches. Kafkas Univ Vet Fak Derg. 24(4), 551-556. DOI: 10.9775/kvfd.2018.19572.

23. Van Halderen, A., Van Rensburg, W.J.J., Geyer, A. and Vorster, J.H. 1994. The identification of Mycoplasma conjunctivae as an aetiological agent of infectious keratoconjunctivitis of sheep in South Africa. Onderstepoort Journal of Veterinary Research 61, 231237.

24. Zheng, W., Porter, E., Noll, L., Stoy, C., Lu, N., Wang, Y., Liu, X., Purvis, T., Peddireddi, L., Lubbers, B., et al., 2019. A multiplex real-time PCR assay for the detection and differentiation of five bovine pinkeye pathogens. Journal of Microbiological Methods 160, 87-92. 